\title{
Endgroup-Assisted Siloxane Bond Cleavage in the Gas Phase
}

\author{
Huiping Chen \\ Analytical Sciences Department, Dow Corning Corporation, Midland, Michigan, USA
}

\begin{abstract}
Unimolecular dissociation of $\mathrm{H}_{2} \mathrm{~N}\left(\mathrm{CH}_{2}\right)_{3} \mathrm{SiOSi}\left(\mathrm{CH}_{2}\right)_{3} \mathrm{NH}_{3}^{+}$generates $\mathrm{SiC}_{5} \mathrm{H}_{16} \mathrm{NO}^{+}$and $\mathrm{SiC}_{5} \mathrm{H}_{14} \mathrm{~N}^{+}$. The formation of $\mathrm{SiC}_{5} \mathrm{H}_{16} \mathrm{NO}^{+}$involves dissociation of a $\mathrm{Si}-\mathrm{O}$ bond and formation of an $\mathrm{O}-\mathrm{H}$ bond through rearrangement. The fragmentation mechanism was investigated utilizing ab initio calculations and Fourier transform ion cyclotron resonance (FTICR) mass spectrometry in combination with hydrogen/deuterium (H/D) exchange reactions. Sustained off-resonance irradiation collision-induced dissociation (SORI-CID) studies of the fully deuterated ion $\mathrm{D}_{2} \mathrm{~N}\left(\mathrm{CH}_{2}\right)_{3} \mathrm{SiOSi}\left(\mathrm{CH}_{2}\right)_{3} \mathrm{ND}_{3}^{+}$provided convincing evidence for a backbiting mechanism which involves hydrogen transfer from the terminal amine group to the oxygen to form a silanol-containing species. Theoretical calculations indicated decomposition of $\mathrm{H}_{2} \mathrm{~N}\left(\mathrm{CH}_{2}\right)_{3} \mathrm{SiOSi}\left(\mathrm{CH}_{2}\right)_{3} \mathrm{NH}_{3}^{+}$through a backbiting mechanism is the lowest energy decomposition channel, compared with other alternative routes. Two mechanisms were proposed for the fragmentation process which leads to the siloxane bond cleavage and the SORI-CID results of partially deuterated precursor ions suggest both mechanisms should be operative. Rearrangement to yield a silanol-containing product ion requires end groups possessing a labile hydrogen atom. Decomposition of disiloxane ions with end groups lacking labile hydrogen atoms yielded product ions from direct bond cleavages. (J Am Soc Mass Spectrom 2003, 14, 1039-1048) ( 2003 American Society for Mass Spectrometry
\end{abstract}

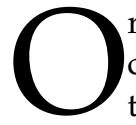
rganosilicon compounds have numerous applications in a variety of different industries due to their unique chemical and physical properties [1-3]. For example, small organosilanes such as $\left(\mathrm{CH}_{3}\right)_{3} \mathrm{SiH}$ are used in chemical vapor deposition (CVD) processes for semiconductor applications [4, 5]. Silicone fluids with different viscosities are often found in personal care products [6]. Silsesquioxane resins with desirable electrical, optical, and mechanical properties have been widely applied as electrically insulating coatings or protective coatings against heat or abrasion $[7,8]$.

Characterization of silicon-containing species by mass spectrometry has been practiced for many years. Gas chromatography mass spectrometry (GC-MS) is applicable for relatively small and volatile organosilicon compounds [9]. Field desorption (FD) mass spectrometry has proved useful for polysiloxane analysis [9]. Recent development of soft ionization techniques such as matrix-assisted laser desorption/ionization (MALDI) [10-12] and electrospray ionization (ESI) [13, 14] make mass spectrometry an even more valuable

Published online July 21, 2003

Address reprint requests to Dr. H. Chen, Analytical Sciences Department, Dow Corning Corporation, 2200 W. Salzburg Road, Mail Stop CO41D1, Midland, MI 48686, USA. E-mail: huiping.chen@dowcorning.com analytical tool enabling better fundamental understanding of organosilicon chemistry [15-20].

Silicone materials with reactive organic functional groups are often important intermediates for synthesizing new compounds. Characterization of these materials by mass spectrometry, even with soft ionization techniques, can be very challenging due to decomposition of activated molecular ions. The presence of heteroatoms within organic ligands covalently bonded to silicon can have significant effects upon the fragmentation pattern. Fundamental understanding of the gasphase behavior of these silicon-containing species helps reduce the complexity of mass spectral data for these complex samples.

Maziarz et al. reported a detailed study of an $\alpha, \omega-$ bis(3-aminopropyl) polydimethysiloxane (AP-PDMS) polymer using electrospray ionization Fourier transform ion cyclotron resonance mass spectrometry (ESIFTICR MS) [21]. A minor series of ions corresponding to hydroxy terminated polymers were observed and a hydrogen exchange fragmentation mechanism was proposed (Scheme 1). Shortly after, Maziarz et al. reported another study of an $\alpha, \omega$-bis(4-hydroxybutyl) polydimethysiloxane (HB-PDMS) and oligomers end capped with one hydroxy end group were also observed [22]. A different mechanism (backbiting mechanism) was proposed for the latter case, in contrast to the mechanism proposed for the former case. We recently analyzed an 


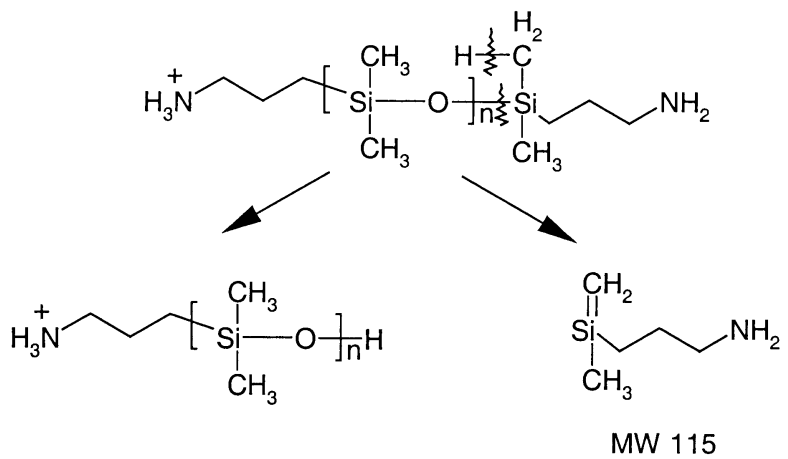

Scheme 1. Proposed hydrogen exchange fragmentation mechanism for AP-PDMS polymer [21].

$\alpha, \omega$-bis(3-carboxypropyl) polydimethysiloxane (CPPDMS) polymer by electrospray ionization mass spectrometry (ESI-MS). When collisionally activated, the CP-PDMS ions fragmented via a rearrangement process to yield hydroxy terminated products (i.e., silanolcontaining species). Silanol-containing species were also observed in the MS/MS experiments of an $\alpha, \omega$ bis(3-hydroxypropyl) polydimethysiloxane (HP-PDMS) polymer as well as for an AP-PDMS. The tandem mass spectrometric results indicate that there is a systematic formation of silanol-containing species for the siloxane polymers being investigated. One common feature of these polymers is that they all have labile hydrogen atoms present on the end groups. As a comparison, PDMS polymers having terminal groups lacking labile hydrogen atoms (such as $-\mathrm{CH}_{2} \mathrm{CH}_{2} \mathrm{CH}_{2} \mathrm{CN}$ ) were found to fragment through a direct cleavage process. These observations suggest that the labile hydrogen atoms on the end group may play an important role in the dissociation of the siloxane bond. Furthermore, an intramolecular backbiting mechanism (Scheme 2), rather than the mechanism shown in Scheme $\mathbf{1}$, may be operative for AP-PDMS.

The origin of the hydrogen atom within the silanol group $(\mathrm{Si}-\mathrm{OH})$ fundamentally differentiates the two different mechanisms shown in Schemes $\mathbf{1}$ and 2. For a better understanding of the fragmentation process, 1,3bis(3-aminopropyl) tetramethyldisiloxane, $\mathrm{H}_{2} \mathrm{~N}\left(\mathrm{CH}_{2}\right)_{3} \mathrm{Me}_{2} \mathrm{SiOSiMe}_{2}\left(\mathrm{CH}_{2}\right)_{3} \mathrm{NH}_{2}(\mathrm{I})$, was chosen as a

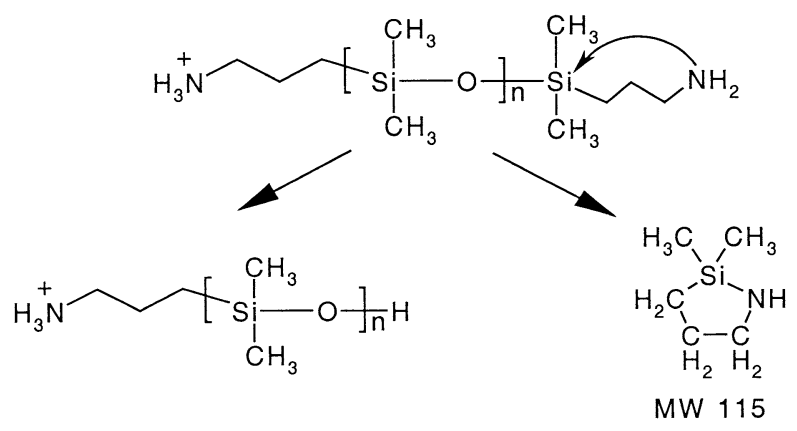

Scheme 2. Proposed backbiting fragmentation mechanism for AP-PDMS polymer. model system for the mechanistic study. The $[\mathrm{M}+\mathrm{H}]^{+}$ ion, $\mathrm{H}_{2} \mathrm{~N}\left(\mathrm{CH}_{2}\right)_{3} \mathrm{Me}_{2} \mathrm{SiOSiMe}_{2}\left(\mathrm{CH}_{2}\right)_{3} \mathrm{NH}_{3}^{+}$(II), was studied using FTICR MS in combination with isotopic labeling experiments. Hydrogen/deuterium (H/D) exchange reactions combined with tandem mass spectrometry have long been used for the determination of structures and reaction mechanisms of gas-phase ions [23-25]. Despite the increasing popularity of gas-phase and in-source H/D exchange approaches, it was determined that a solution-phase H/D exchange experiment was well suited for the present study. Specifically, when Structure II is fully deuterated as $\mathrm{D}_{2} \mathrm{~N}\left(\mathrm{CH}_{2}\right)_{3} \mathrm{Me}_{2} \mathrm{SiOSiMe}_{2}\left(\mathrm{CH}_{2}\right)_{3} \mathrm{ND}_{3}^{+}\left(\mathrm{II}-\mathrm{D}_{5}\right)$, and the mechanism depicted in Scheme $\mathbf{1}$ is operative, the fragment ion should contain a $\mathrm{Si}-\mathrm{OH}$ group. If a backbiting mechanism is operative, a Si-OD group is expected. The unimolecular fragmentation of Structure II was also studied by ab initio calculations. The energetic requirements for different fragmentation pathways dictated by different mechanisms were compared using the computational data. These data combined with experimental results will be discussed in greater detail.

\section{Experimental}

\section{Materials}

The organosiloxane materials (1,3-bis(3-aminopropyl) tetramethyldisiloxane, 1,3-bis(3-hydroxypropyl) tetramethyldisiloxane, and 1,3-bis(3-carboxypropyl) tetramethyldisiloxane) were purchased from Gelest Inc. (Tullytown, PA) and used without further purification. Two other organosiloxane materials, 1,3-bis(3-cyanopropyl) tetramethyldisiloxane and 1-(3-cyanopropyl)-3(3-aminopropyl) tetramethyldisiloxane, are present as impurities in 1,3-bis(3-carboxypropyl) tetramethyldisiloxane. The organic solvents used for sample preparation were obtained from Fisher Scientific (Fair Lawn, $\mathrm{NJ})$. All deuterated reagents were purchased from Isotec, Inc. (Miamisburg, OH).

\section{Mass Spectrometry}

ESI-FTICR MS analyses were performed on a Bruker (Billerica, MA) Apex II instrument equipped with a 4.7-T superconducting magnet and an external Analytica ESI source (Branford, CT). A Cole-Parmer (Vernon Hills, IL) series 74900 syringe pump was used to continuously infuse samples into the ESI source at a flow rate of $0.3 \mathrm{~mL} \mathrm{~h}^{-1}$. The external electrospray ion source was operated with a $45^{\circ}$ off-axis sprayer. High purity $(99.995 \%)$ nitrogen gas was used as both nebulizing gas at ambient temperature and as a drying gas at $105^{\circ} \mathrm{C}$. An electrostatic potential of ca. $-4.7 \mathrm{kV}$ (relative to the grounded needle) was applied to the metalcapped glass capillary in the positive-ion mode. Ions were accumulated in a hexapole ion guide, adjacent to the external ESI source, and were subsequently injected into the INFINITY cell using the patented Sidekick 


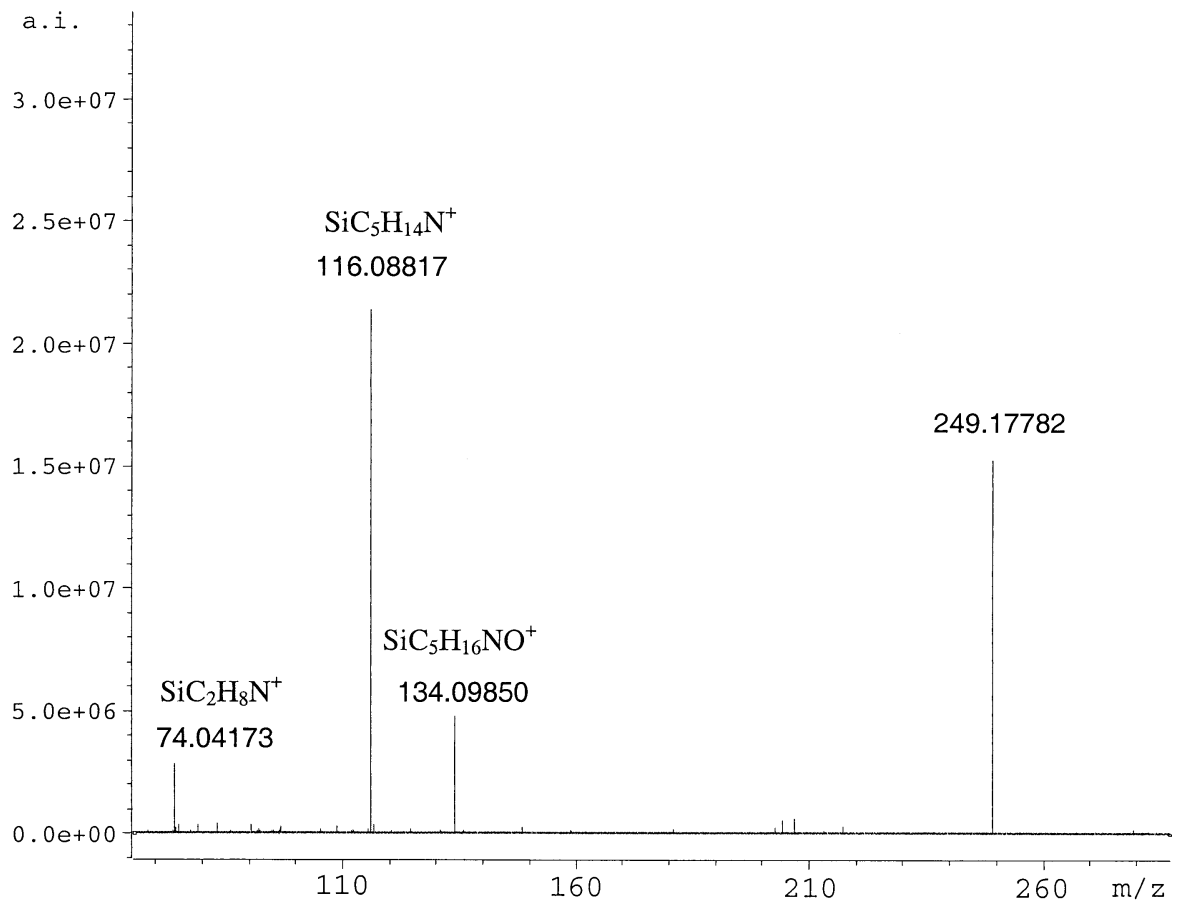

Figure 1. SORI-CID spectrum of II at $m / z 249$.

method. Data acquired in the broadband mode were typically collected using $128 \mathrm{k}$ data points.

Sustained off-resonance irradiation (SORI) [26] experiments were performed for the collision-induced dissociation (CID) studies. The off-resonance excitation was applied for $250 \mathrm{~ms}$ at $1000 \mathrm{~Hz}$ above the cyclotron resonance frequency for the ion of interest. High purity argon gas was pulsed into the ICR cell and a 3 s delay was used following the SORI-CID event.

CID spectra of 1,3-bis(3-cyanopropyl) tetramethyldisiloxane and 1-(3-cyanopropyl)-3-(3-aminopropyl) tetramethyldisiloxane were collected using a PE Sciex API 350 triple quadrupole (Thornhill, Ontario, Canada) mass spectrometer equipped with an ion spray source. High purity nitrogen was used as the collision gas for the CID experiments. The collision energy for both samples was set to $20 \mathrm{eV}$ and the signal was averaged over 10 or 20 scans.

Sample solutions for ESI analysis were prepared by dissolving ca. $1 \mu \mathrm{L}$ into $5 \mathrm{~mL}$ of a 1:1 mixture of $\mathrm{CHCl}_{3} / \mathrm{MeOH}$. Solution phase $\mathrm{H} / \mathrm{D}$ exchange was achieved by dissolving $1 \mu \mathrm{L}$ of the disiloxane sample in $5 \mathrm{~mL}$ of a 1:1:1 mixture of $\mathrm{CDCl}_{3} / \mathrm{MeOD} / \mathrm{D}_{2} \mathrm{O}$ for $6 \mathrm{~h}$ prior to the ESI analyses.

\section{Computational}

$\mathrm{Ab}$ initio calculations were performed using the Gaussian 98 program suite [27]. Geometry optimizations were performed at the Hartree-Fock (HF) self-consistent-field

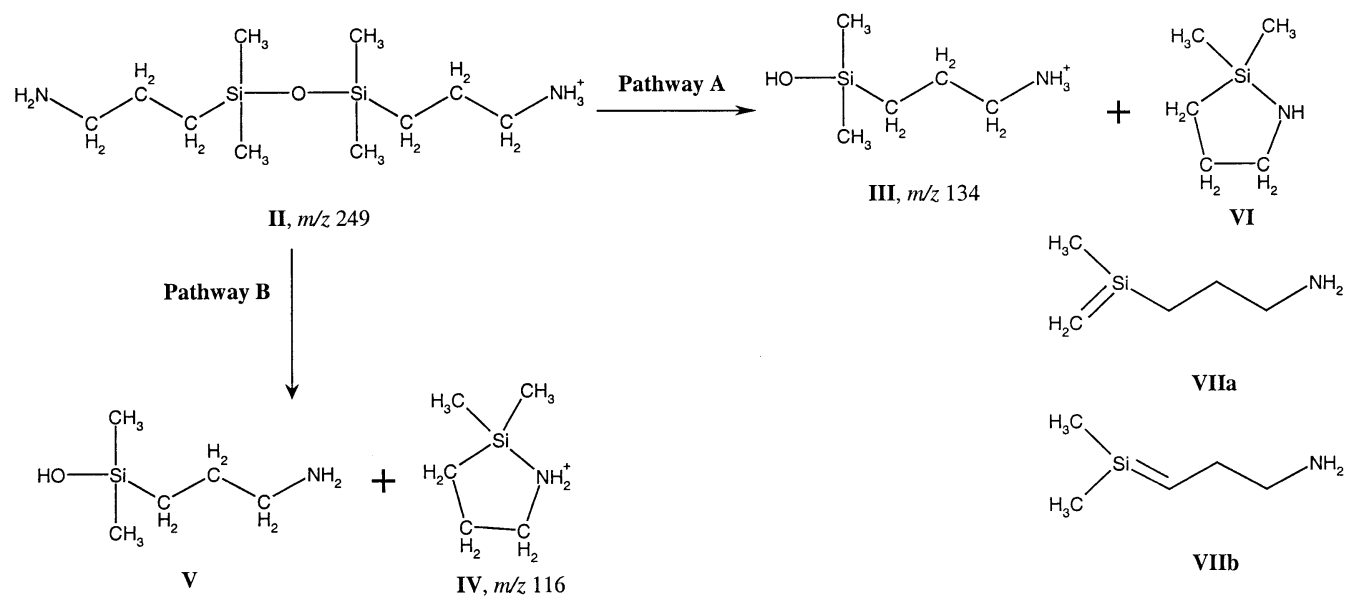

Scheme 3 
Table 1. Computational data for various species related to the unimolecular dissociation of $\mathbf{I I}^{\mathbf{a}}$

\begin{tabular}{|c|c|c|c|}
\hline Species & $\begin{array}{c}\text { Energy at } \\
\mathrm{HF} / 6-311 \mathrm{G} \\
\text { level }\end{array}$ & $\begin{array}{l}\text { Dissociation } \\
\text { reaction }\end{array}$ & $\begin{array}{c}\text { Reaction } \\
\text { energy }\end{array}$ \\
\hline I & -1156.182343 & $\mathrm{II} \rightarrow \mathrm{III}+\mathrm{VI}$ & 10.0 \\
\hline II & -1156.367628 & $\mathrm{II} \rightarrow \mathrm{III}+$ VIla & 68.5 \\
\hline III & -616.286534 & $\mathrm{II} \rightarrow \mathrm{III}+\mathrm{VIIb}$ & 67.9 \\
\hline IV & -540.343894 & $\mathrm{II} \rightarrow \mathrm{IV}+\mathrm{V}$ & 36.6 \\
\hline V & -615.965409 & $\mathbf{I V} \rightarrow \mathbf{V} \mathbf{I}+\mathrm{H}^{+\mathbf{b}}$ & 174.9 \\
\hline VI & -540.065216 & $\mathrm{III} \rightarrow \mathbf{V}+\mathrm{H}^{+\mathrm{b}}$ & 201.5 \\
\hline VIla & -539.971970 & III $\rightarrow$ IV $+\mathrm{H}_{2} \mathrm{O}$ & -28.7 \\
\hline VIllb & -539.972948 & & \\
\hline $\mathrm{H}_{2} \mathrm{O}$ & -75.988336 & & \\
\hline
\end{tabular}

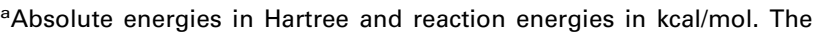
absolute energies have been corrected for ZPE.

${ }^{\mathrm{b}}$ Reaction energy equal to proton affinity of the neutral molecule.

(SCF) level of theory using the 6-311G basis set and frequency calculations were also conducted at the same level. All stationary points were characterized as minima or first-order transition structures by evaluating the frequencies and normal modes by using analytical first derivatives and the computed force constant matrix. Energies reported in the text are corrected for zero point energies (ZPE).

\section{Results and Discussion}

1,3-Bis(3-aminopropyl) tetramethyldisiloxane (I) was analyzed by ESI-FTICR MS and a typical SORI-CID spectrum of the $\left[\mathrm{M}+\mathrm{H}^{+}\right.$ion, $\mathrm{H}_{2} \mathrm{~N}\left(\mathrm{CH}_{2}\right)_{3} \mathrm{Me}_{2} \mathrm{SiOSiMe}_{2}\left(\mathrm{CH}_{2}\right)_{3} \mathrm{NH}_{3}^{+}$(II, $m / z$ 249), is shown in Figure 1. Only three fragment ions were observed and the exact mass measurements allow unambiguous assignments of the empirical formula of these species. The ion at $m / z 74.04173$ corresponds to $\mathrm{SiC}_{2} \mathrm{H}_{8} \mathrm{~N}^{+}$. Its formation likely involves extensive bond cleavages and rearrangements, and is not the focus of attention here. The other two fragment ions, $\mathrm{m} / \mathrm{z}$ 134.09850 and 116.08817, correspond to $\mathrm{SiC}_{5} \mathrm{H}_{16} \mathrm{NO}^{+}$ and $\mathrm{SiC}_{5} \mathrm{H}_{14} \mathrm{~N}^{+}$, respectively. The mass difference be- tween these two species (18.01033) corresponds to a water molecule. The formation of these ions is likely due to the two competitive fragmentation Pathways A and $\mathrm{B}$, as described in Scheme 3. The $\mathrm{SiC}_{5} \mathrm{H}_{16} \mathrm{NO}^{+}$ion was generated with a loss of $\mathrm{SiC}_{5} \mathrm{H}_{13} \mathrm{~N}$ via fragmentation Pathway A. For the $\mathrm{SiC}_{5} \mathrm{H}_{14} \mathrm{~N}^{+}$ion, there are two possibilities. It may result from the competitive fragmentation Pathway B, as well as from further fragmentation of $\mathrm{SiC}_{5} \mathrm{H}_{16} \mathrm{NO}^{+}$via a water loss. A double resonance experiment was carried out in which SORI-CID of II was performed with continuous ejection of the $\mathrm{SiC}_{5} \mathrm{H}_{16} \mathrm{NO}^{+}$ion, and the results eliminated the latter possibility.

The most likely structure for the $\mathrm{SiC}_{5} \mathrm{H}_{16} \mathrm{NO}^{+}$empirical formula is Structure III. The formation of this silanol-containing species involved dissociation of a $\mathrm{Si}-\mathrm{O}$ bond and formation of an $\mathrm{O}-\mathrm{H}$ bond. Depending upon the fragmentation mechanism, the structure of the leaving neutral molecule, $\mathrm{SiC}_{5} \mathrm{H}_{13} \mathrm{~N}$, could be significantly different. If the backbiting mechanism is operative, the cyclic Structure VI should be most likely. Otherwise, Structure VIIa is likely formed if the hydrogen atom of the silanol group originates from the methyl group on silicon atom via the mechanism described in Scheme 1. VIIb is an isomeric structure of VIIa. Its formation requires that the hydrogen atom originate from the secondary carbon that is adjacent to the silicon atom. Experimentally, SORI-CID of II to form III was found to be a facile process of which little energy was required to induce the dissociation. However, for a more quantitative measure, it is worthwhile to compare the energy requirements for the three fragmentation channels: (1) II $\rightarrow$ III + VI; (2) II $\rightarrow$ III + VIIa; and (3) II $\rightarrow$ III + VIIb.

The geometries of various species under investigation were optimized at Hartree-Fock (HF) level using the 6-311G basis set, and a single point calculation was performed using the optimized structure to obtain the energy for individual species. Zero point energy (ZPE) was corrected from the total energy and all results are summarized in Table 1.

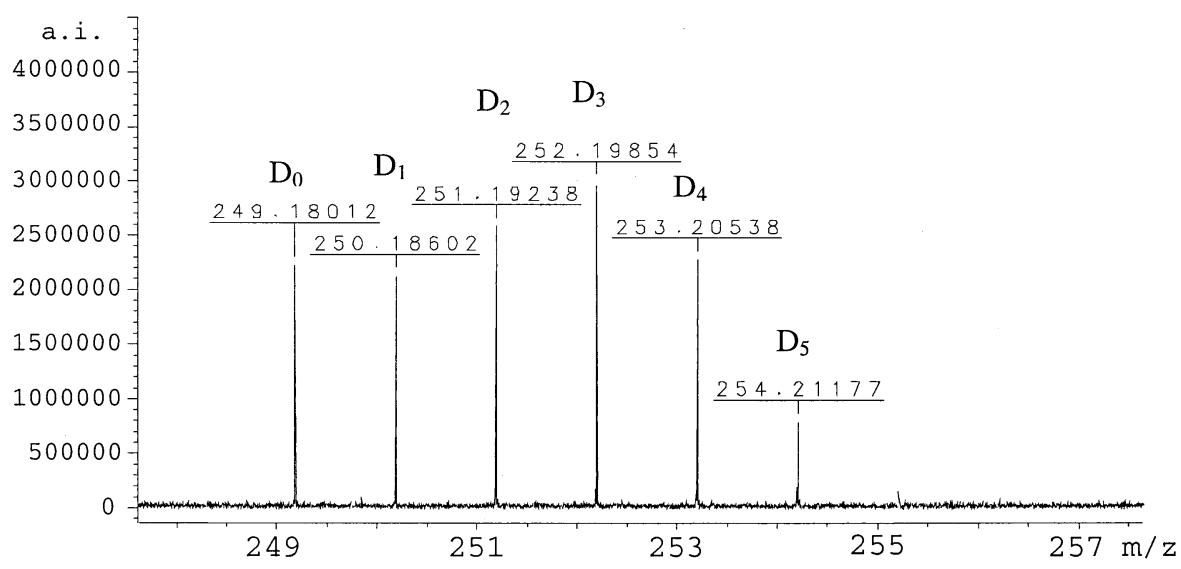

Figure 2. ESI FTICR mass spectrum of II resulting from solution-phase H/D exchange reactions. 
We now take a close look at the energies of the three isomers VI, VIIa, and VIIb. Clearly, the cyclic species VI is 58.5 and $57.9 \mathrm{kcal} / \mathrm{mol}$ more stable than VIIa and VIIb, respectively. Consequently, of the three fragmentation channels associated with Pathway A, II $\rightarrow$ III + VI is the lowest energy-demanding process. It only requires $10 \mathrm{kcal} / \mathrm{mol}$, compared to 68.5 and $67.9 \mathrm{kcal} /$ mol for II $\rightarrow$ III + VIIa and II $\rightarrow$ III + VIIb, respectively. Energetically, the mechanism shown in Scheme $\mathbf{1}$ is highly unfavorable.

Fragmentation Pathway B yielded $\mathrm{SiC}_{5} \mathrm{H}_{15} \mathrm{NO}$ loss to generate $\mathrm{SiC}_{5} \mathrm{H}_{14} \mathrm{~N}^{+}$. A cyclic Structure IV is preferred for $\mathrm{SiC}_{5} \mathrm{H}_{14} \mathrm{~N}^{+}$due to the following considerations. First, further decomposition of $\mathrm{SiC}_{5} \mathrm{H}_{16} \mathrm{NO}^{+}$(III) could generate $\mathrm{SiC}_{5} \mathrm{H}_{14} \mathrm{~N}^{+}$through an $\mathrm{H}_{2} \mathrm{O}$ loss. A cyclic product ion is likely formed since the active sites include a silanol group and an amine end group. Second, II $\rightarrow$ III + VI is the most likely decomposition channel of II if based solely upon energy requirements. If cyclic Structure VI is preferred for formation of $\mathrm{SiC}_{5} \mathrm{H}_{13} \mathrm{~N}$ in Pathway A, cyclic Structure IV is the most likely structure for $\mathrm{SiC}_{5} \mathrm{H}_{14} \mathrm{~N}^{+}$for competitive Pathway B. Consequently, the calculated energy requirement for $\mathbf{I I} \rightarrow \mathbf{I V}+\mathbf{V}$ is 36.6 $\mathrm{kcal} / \mathrm{mol}, 26.6 \mathrm{kcal} / \mathrm{mol}$ higher than that required for II $\rightarrow$ III + VI. Obviously, the energy difference between Pathways $\mathrm{A}$ and $\mathrm{B}$ corresponds to the proton affinity (PA) difference between Structures VI and V. The calculated $\mathrm{PA}$ of $\mathbf{V}$ is $201.5 \mathrm{kcal} / \mathrm{mol}, 26.6 \mathrm{kcal} / \mathrm{mol}$ higher than that of VI $(174.9 \mathrm{kcal} / \mathrm{mol})$ [28]. As mentioned previously, further decomposition of $\mathrm{SiC}_{5} \mathrm{H}_{16} \mathrm{NO}^{+}$to generate $\mathrm{SiC}_{5} \mathrm{H}_{14} \mathrm{~N}^{+}$through $\mathrm{H}_{2} \mathrm{O}$ loss $\left(\mathrm{III} \rightarrow \mathrm{IV}+\mathrm{H}_{2} \mathrm{O}\right)$ is a process that is $28.7 \mathrm{kcal} / \mathrm{mol}$ exothermic.

Further evidence for the fragmentation mechanism of II was obtained through a designed H/D exchange experiment. H/D exchange reactions are often used in conjunction with MS techniques to probe the gas-phase structures for the ions of interest, and to study their fragmentation mechanisms. H/D exchange reactions generally involve labile protons associated with functional groups such as $-\mathrm{OH},-\mathrm{SH},-\mathrm{COOH}$, and $-\mathrm{NH}_{2}$. The $\mathrm{H} / \mathrm{D}$ exchange reactions can be conducted in solution prior to MS analysis or in the gas phase using a fully deuterated reagent such as $\mathrm{D}_{2} \mathrm{O}$ or $\mathrm{ND}_{3}$. In this case, a solution-phase $\mathrm{H} / \mathrm{D}$ exchange experiment was conducted to shed some light on the fragmentation mechanism of II and the origin of the hydrogen atom present in the silanol group of III. To achieve this, a sample containing $\mathrm{H}_{2} \mathrm{~N}\left(\mathrm{CH}_{2}\right)_{3}$ $\mathrm{Me}_{2} \mathrm{SiOSiMe}_{2}\left(\mathrm{CH}_{2}\right)_{3} \mathrm{NH}_{2}$ was first dissolved in a mixture of $\mathrm{CDCl}_{3}, \mathrm{MeOD}$, and $\mathrm{D}_{2} \mathrm{O}$ for six hours before the sample solution was electrosprayed into the ESI source. As shown in Figure 2, exchanges of up to five labile hydrogen atoms were observed for II. The fact that the exchange did not go to completion was attributed to the use of aged $\mathrm{D}_{2} \mathrm{O}$ with significant $\mathrm{H}_{2} \mathrm{O}$ content. Figure 3 illustrates the SORI-CID spectra obtained for partially and fully deuterated II. The relative peak intensities for the product ions are summarized in Table 2.

We first consider a fully deuterated precursor ion, II- $D_{5}(m / z 254)$. According to Scheme 4, two product

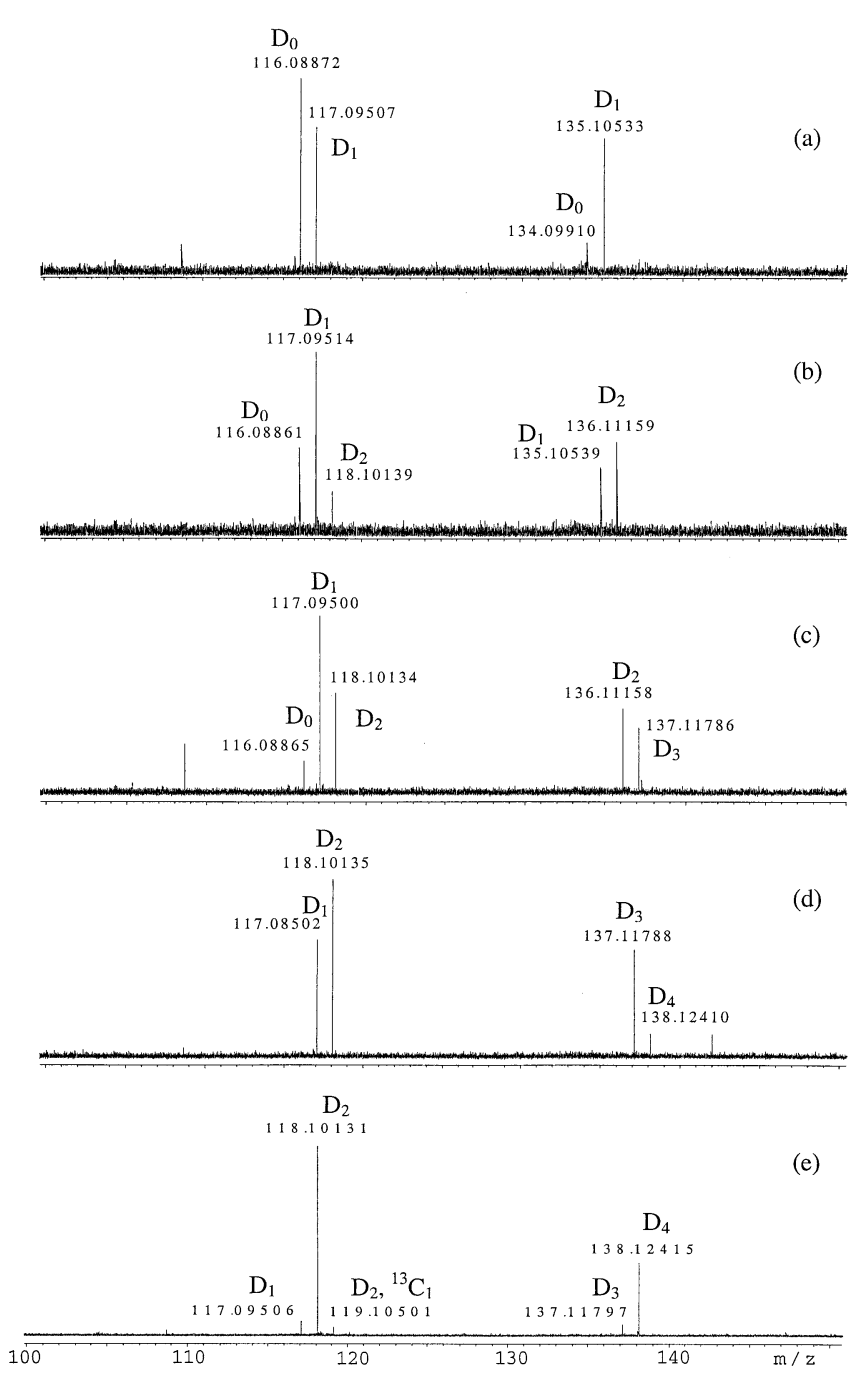

Figure 3. SORI-CID spectra of the deuterium-labeled ion at (a) $m / z 250\left(\mathbf{D}_{1}\right),(\mathbf{b}) m / z 251\left(\mathbf{D}_{2}\right),(\mathbf{c}) m / z 252\left(\mathbf{D}_{3}\right),(\mathbf{d}) \mathrm{m} / z 254\left(\mathbf{D}_{4}\right)$, and (e) $m / z 255\left(\mathbf{D}_{5}\right)$. The subscripts of the labeled peaks denote the number of incorporated deuterium or ${ }^{13} \mathrm{C}$ isotopes for the selected species.

ions, $m / z 138$ and $m / z$ 118, are expected from the backbiting mechanism. If the hydrogen atom were transferred from the methyl group on the silicon atom, the $m / z 137$ ion and the $m / z 119$ ion should be observed. Shown in Figure 3 is the SORI-CID mass spectrum of II-D ${ }_{5}(m / z 254)$ which contains predominantly the $m / z$ 118 ion (88.8\%) and the $\mathrm{m} / \mathrm{z} 138$ ion (86.4\%), thus supporting the backbiting mechanism.

Based upon the small percentage $(4.2 \%)$ of the $\mathrm{m} / \mathrm{z}$ 119 ion, it appears that we cannot completely exclude the mechanism described in Scheme 1. However, due to the presence of partially deuterated species, the precursor ion at $m / z 254$ should include II $\left(D_{5}\right)$ as well as the isotopes of other species such as II $\left(\mathrm{D}_{4},{ }^{13} \mathrm{C}\right)$. Therefore, the $m / z 119$ ion is very likely due to VI $\left(D_{2},{ }^{13} \mathrm{C}\right)$ and an accurate mass measurement $(\mathrm{m} / \mathrm{z}$ 119.10501) confirmed this assignment. Theoretical $m / z$ values for VI $\left(D_{2},{ }^{13} \mathrm{C}\right)$ and VIIa $\left(D_{3}\right)$ are 119.10540 and 119.10833 , respectively. These data further exclude the mechanism that involves 
Table 2. Relative intensity for the fragment ions of deuterium-labeled II

\begin{tabular}{|c|c|c|c|c|c|c|c|c|c|}
\hline \multirow{2}{*}{$\begin{array}{l}\text { Precursor ion } \\
(\mathrm{m} / \mathrm{z})\end{array}$} & \multicolumn{9}{|c|}{ Fragment Ion Distribution (\%) } \\
\hline & $\mathrm{m} / \mathrm{z} 116$ & $m / z 117$ & $\mathrm{~m} / \mathrm{z} 118$ & $m / z 119$ & $m / z 134$ & $m / z 135$ & $\mathrm{~m} / \mathrm{z} 136$ & $\mathrm{~m} / \mathrm{z} 137$ & $\mathrm{~m} / \mathrm{z} 138$ \\
\hline 250 & $\begin{array}{l}57.9 \\
(60)\end{array}$ & $\begin{array}{l}42.1 \\
(40)\end{array}$ & - & - & $\begin{array}{l}19.5 \\
(20)\end{array}$ & $\begin{array}{l}80.5 \\
(80)\end{array}$ & - & - & - \\
\hline 251 & $\begin{array}{l}27.9 \\
(30)\end{array}$ & $\begin{array}{l}57.9 \\
(60)\end{array}$ & $\begin{array}{c}14.2 \\
(10)\end{array}$ & - & - & $\begin{array}{l}42.3 \\
(40)\end{array}$ & $\begin{array}{l}57.7 \\
(60)\end{array}$ & - & - \\
\hline 252 & $\begin{array}{l}10.8 \\
(10)\end{array}$ & $\begin{array}{l}56.6 \\
(60)\end{array}$ & $\begin{array}{r}32.6 \\
(30)\end{array}$ & - & - & - & $\begin{array}{l}56.3 \\
(60)\end{array}$ & $\begin{array}{l}43.7 \\
(40)\end{array}$ & - \\
\hline 253 & - & $\begin{array}{l}39.7 \\
(40)\end{array}$ & $\begin{array}{r}60.3 \\
(60)\end{array}$ & - & - & - & - & $\begin{array}{l}81.6 \\
(80)\end{array}$ & $\begin{array}{c}18.4 \\
(20)\end{array}$ \\
\hline 254 & - & 7.0 & $\begin{array}{c}88.8 \\
(100)\end{array}$ & 4.2 & - & - & - & 13.6 & $\begin{array}{c}86.4 \\
(100)\end{array}$ \\
\hline
\end{tabular}

Note: The numbers in parenthesis are the theoretical percentages predicted according to Mechanisms A and B.

the transfer of a hydrogen atom from the methyl group on the silicon. The low intensities observed for the $\mathrm{m} / \mathrm{z}$ 117 and 137 ions in Figure 3e are very likely due to partially deuterated precursor ions as well.

We have demonstrated by means of an H/D exchange experiment and SORI-CID experiments that amine end groups play an important role in the formation of silanol-containing species from the decomposition of Structure II. In other words, the backbiting mechanism is solely responsible for the dissociation of siloxane bond. However, "backbiting mechanism" is probably too general a term to provide any specific information about the fragmentation processes. For precursor ion II, the neutral amine and the protonated amine is a Lewis base and a Brönsted acid, respectively. We believe that they can both initiate the siloxane bond dissociation and generate different product ions.

Scheme 5 illustrates Mechanism A that describes an intramolecular nucleophilic substitution reaction. The reaction may proceed through a four-centered intermediate, stabilized by hydrogen bonding between the oxygen in the $\mathrm{Si}-\mathrm{O}$ bond and the amine hydrogen. Compared to a $\mathrm{C}-\mathrm{O}$ bond, the oxygen in $\mathrm{Si}-\mathrm{O}$ is richer in electron density, which makes it a more favorable site for hydrogen bonding. This type of mechanism has been proposed previously to explain stereochemical retention of certain nucleophilic substitution reactions $[3,29,30]$. The four-centered intermediate requires that the functional end group possesses a labile hydrogen atom needed for stabilizing the intermediate through hydrogen bonding and for subsequent hydrogen transfer to the oxygen at a later stage. Decomposition of II via Mechanism A yields III at $m / z 134$.

In contrast, Mechanism B shown in Scheme 6 describes an acid-initiated intramolecular reaction. In the condensed phase, Brönsted acids are frequently used as acidic catalysts to initiate ring-opening polymerization reactions of silicones. In this case, the protonated amine, a Brönsted acid, should be able to catalyze the siloxane bond cleavage as well. Initial proton transfer to the oxygen generates an oxonium ion. Subsequent nucleophilic attack of the silicon by the amine nitrogen yields the product ion IV at $m / z 116$.

If III and IV were generated, as we propose, via Mechanisms A and B respectively, SORI-CID results of the partially deuterated analogues of II should provide us further insights into the decomposition process. Figure 3 includes the SORI-CID spectra of all partially deuterated II and the relative intensities for their product ions are summarized in Table 2. Take a precursor ion, II- $\mathbf{D}_{1}(\mathrm{~m} / \mathrm{z}$ $250)$, as an example. The probability ratio of $\mathrm{H}_{2} \mathrm{~N}\left(\mathrm{CH}_{2}\right)_{3} \mathrm{Si}$ $\left(\mathrm{CH}_{3}\right)_{2} \mathrm{OSi}\left(\mathrm{CH}_{3}\right)_{2}\left(\mathrm{CH}_{2}\right)_{3} \mathrm{NH}_{2} \mathrm{D}^{+}$and $\mathrm{HDN}\left(\mathrm{CH}_{2}\right)_{3} \mathrm{Si}\left(\mathrm{CH}_{3}\right)_{2}$ $\mathrm{OSi}\left(\mathrm{CH}_{3}\right)_{2}\left(\mathrm{CH}_{2}\right)_{3} \mathrm{NH}_{3}^{+}$is 3:2, based upon statistical considerations. Following Mechanisms $\mathrm{A}$ and $\mathrm{B}$, decomposition of $\mathrm{H}_{2} \mathrm{~N}\left(\mathrm{CH}_{2}\right)_{3} \mathrm{Si}\left(\mathrm{CH}_{3}\right)_{2} \mathrm{OSi}\left(\mathrm{CH}_{3}\right)_{2}\left(\mathrm{CH}_{2}\right)_{3} \mathrm{NH}_{2} \mathrm{D}^{+}$yields $100 \%$ of the $\mathrm{m} / \mathrm{z} 135$ ion, and $1 / 3$ of the $\mathrm{m} / \mathrm{z} 116$ ion, $2 / 3$ of the $m / z 117$ ion. Similarly, decomposition of HDN $\left(\mathrm{CH}_{2}\right)_{3} \mathrm{Si}\left(\mathrm{CH}_{3}\right)_{2} \mathrm{OSi}\left(\mathrm{CH}_{3}\right)_{2}\left(\mathrm{CH}_{2}\right)_{3} \mathrm{NH}_{3}^{+}$yields $50 \%$ the

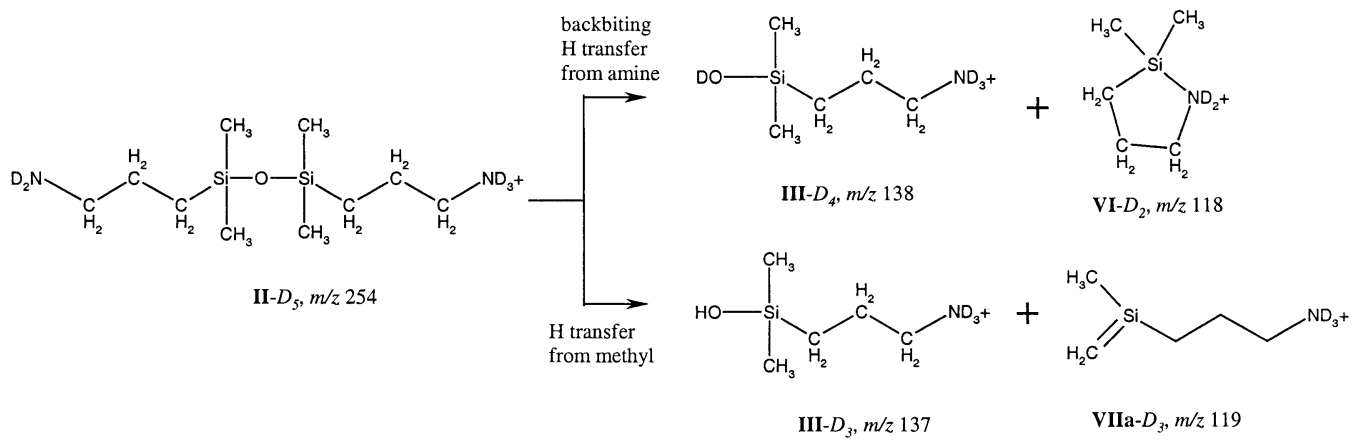

Scheme 4 


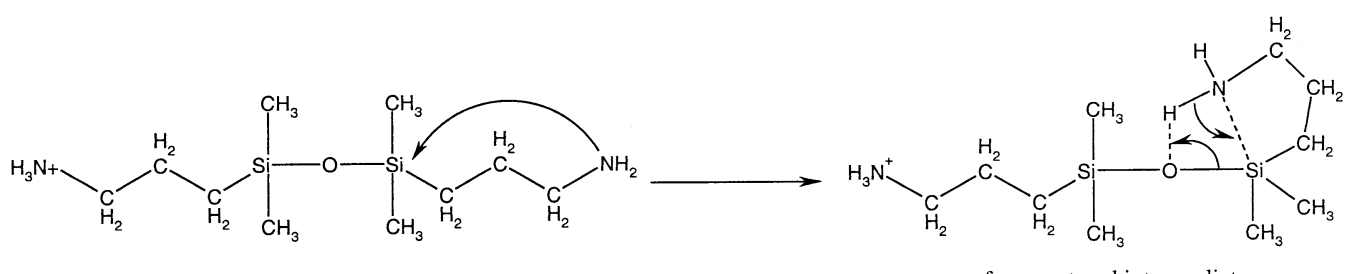

II, $m / z 249$

four-centered intermediate

Mechanism A<smiles>C[Si](C)(O)CCC[NH3+]</smiles>

Scheme 5

$\mathrm{m} / \mathrm{z} 134$ ion, $50 \%$ of the $\mathrm{m} / \mathrm{z} 135$ ion, and $100 \%$ the $\mathrm{m} / \mathrm{z} 116$ ion. Considering the statistic distribution of isomeric precursor ions, the theoretical percentages of the $\mathrm{m} / \mathrm{z} 116$ ion and the $\mathrm{m} / \mathrm{z} 117$ ion are $60 \%$ and $40 \%$, respectively. The predicted percentages for the $\mathrm{m} / \mathrm{z} 134$ ion and the $\mathrm{m} / \mathrm{z} 135$ ion are $20 \%$ and $80 \%$, respectively. The actual isotopic distributions of the fragment ions of II- $\mathrm{D}_{1}$ are very consistent with the theoretical predictions. This is also the case for other partially deuterated precursor ions, as indicated in Table 2. These results suggest that fragmentation of II proceeds through two competitive pathways following the two mechanisms we have discussed. Overall, formation of silanol-containing species requires that the precursor ion have labile hydrogens within the end groups. To test this hypothesis, four disiloxane molecules shown in Scheme $\mathbf{7}$ were studied by either SORI-CID or conventional CID. These include 1,3-bis(hydroxypropyl)tetramethyldisiloxane (VIII), 1,3-bis(carboxypropyl)-tetramethyldisiloxane (IX), 1,3-bis(cyanopropyl)-tetramethyldisiloxane (X), and 1-(cyanopropyl)-3-(aminepropyl)tetramethyldisiloxane (XI). IX and $\mathbf{X I}$ were analyzed in the negative-ion mode using their corresponding $[\mathrm{M}-\mathrm{H}]^{-}$ ions. VIII and $\mathbf{X}$ were analyzed in the positive-ion mode using their $[\mathrm{M}+\mathrm{H}]^{+}$and $\left[\mathrm{M}+\mathrm{NH}_{4}\right]^{+}$ions, respectively. Such a selection created a number of different scenarios. There are two labile hydrogen atoms in VIII, one on each end group. For the $[\mathrm{M}-\mathrm{H}]^{-}$ion of IX, only one labile hydrogen remains. No labile hydrogen atom is available for $\left[\mathbf{X}+\mathrm{NH}_{4}\right]^{+}$(excluding $\mathrm{NH}_{4}^{+}$) and $[\mathbf{X I}-\mathrm{H}]^{-}$.

SORI-CID of the $\left[\mathrm{M}+\mathrm{H}^{+}\right.$ion of VIII yielded fragment ions at $m / z 117$ and 135, as shown in Figure 4 and the fragmentation pathway therein. The protonation site for Structure VIII is tentatively assigned to the terminal hydroxy group and it is very likely that there is a competitive protonation at the oxygen in the siloxane bond. Although the PA of Structure VIII with a protonation site at the oxygen at the $\mathrm{Si}-\mathrm{O}$ bond is not available, the value for the disiloxane $\mathrm{H}_{3} \mathrm{SiOSiH}_{3}$ should serve as a good estimation. The PA for $\mathrm{H}_{3} \mathrm{SiOSiH}_{3}$ was estimated at 185.3 $\mathrm{kcal} / \mathrm{mol}$ [31]. The PA of an n-propanol $\left(\mathrm{C}_{3} \mathrm{H}_{7} \mathrm{OH}\right)$ is about $190.9 \mathrm{kcal} / \mathrm{mol}$ [32]. The small PA difference for the two potential protonation sites suggests that the $[\mathrm{M}+\mathrm{H}]^{+}$ ion for Structure VIII likely contains isomeric ions which may result in additional fragmentation pathways. How-

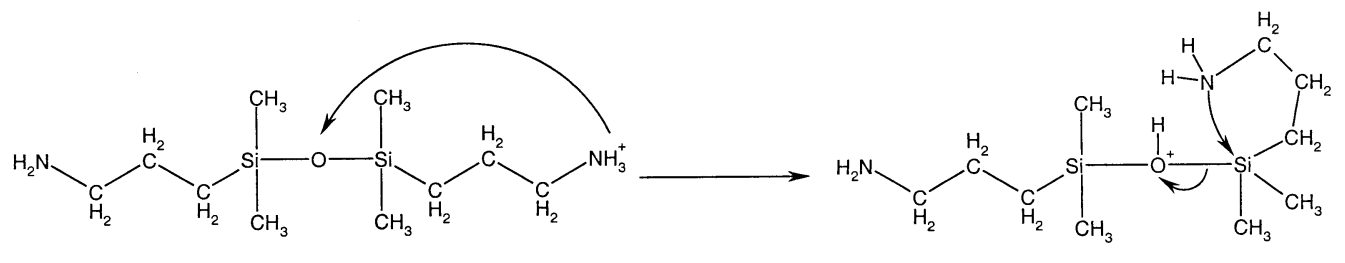

II, $m / z 249$

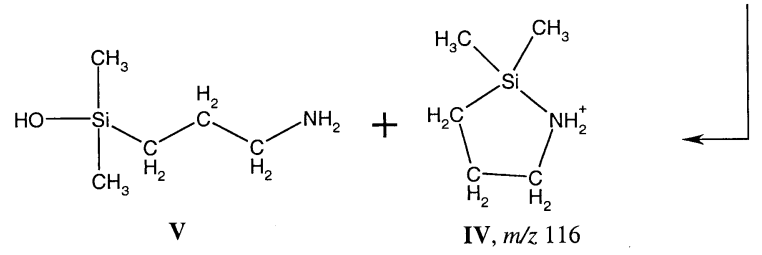

Scheme 6 
<smiles>C[Si](C)(CCCO)O[Si](C)(C)CCCO</smiles>

VIII, MW 250<smiles>C[Si](C)(CCCC#N)O[Si](C)(C)CCCC#N</smiles>

X, MW 268<smiles>C[Si](C)(CCCC(=O)O)O[Si](C)(C)CCCC(=O)O</smiles>

IX, MW 306<smiles>C[Si](C)(CCCC#N)O[Si](C)(C)CCCC(=O)O</smiles>

XI, MW 287

Scheme 7

ever, detailed investigations of these processes is beyond the scope of current investigation. SORI-CID for the [M $\mathrm{H}]^{-}$ion of Structure IX exclusively yielded a fragment ion at $m / z$ 161, a silanol-containing species (Figure 5). It is important to note that silanol-containing product ions were observed in both cases where there are labile hydrogens present within the end groups.

The CID spectrum for the $\left[\mathrm{M}+\mathrm{NH}_{4}\right]^{+}$ion of $\mathbf{X}$ and the $[\mathrm{M}-\mathrm{H}]^{-}$ion of XI are shown in Figures 6 and 7, respectively. As was discussed previously, no labile hydrogen atoms are available for the two precursor ions. Therefore, it is expected that the gas-phase rearrangement processes observed for Structures I, VIII, and IX with labile hydrogen atoms is no longer feasible. Indeed, the predominant fragment ions observed for Structures $\mathbf{X}$ and XI are the ions at $m / z 126$ and 142, respectively, both due to direct cleavage of the precursor ion. The CID experiments were conducted at $20 \mathrm{eV}$ which is the lowest collision energy setting dictated by the instrument. Since the SORI-CID spectra for the $\left[\mathrm{M}+\mathrm{NH}_{4}\right]^{+}$ion of Structure $\mathbf{X}$ and the $[\mathrm{M}-\mathrm{H}]^{-}$ion of Structure $\mathbf{X I}$ were not obtained, one may argue about the absence of silanol-containing species based upon the fact that direct bond cleavages, rather than rearrangements, is often the preferred process during CID. However, in our best judgment, the complete absence of the silanol-containing product ion has nothing to do with the competition of direct bond cleavage and rearrangement. The rearrangement process via the backbiting mechanism involving labile hydrogens on the end groups is simply not a viable option for molecules such as $\mathbf{X}$ and $\mathbf{X I}$.

\section{Conclusions}

PDMS polymers with reactive functional end groups such as propylamine, propylhydroxy, and propylcar-

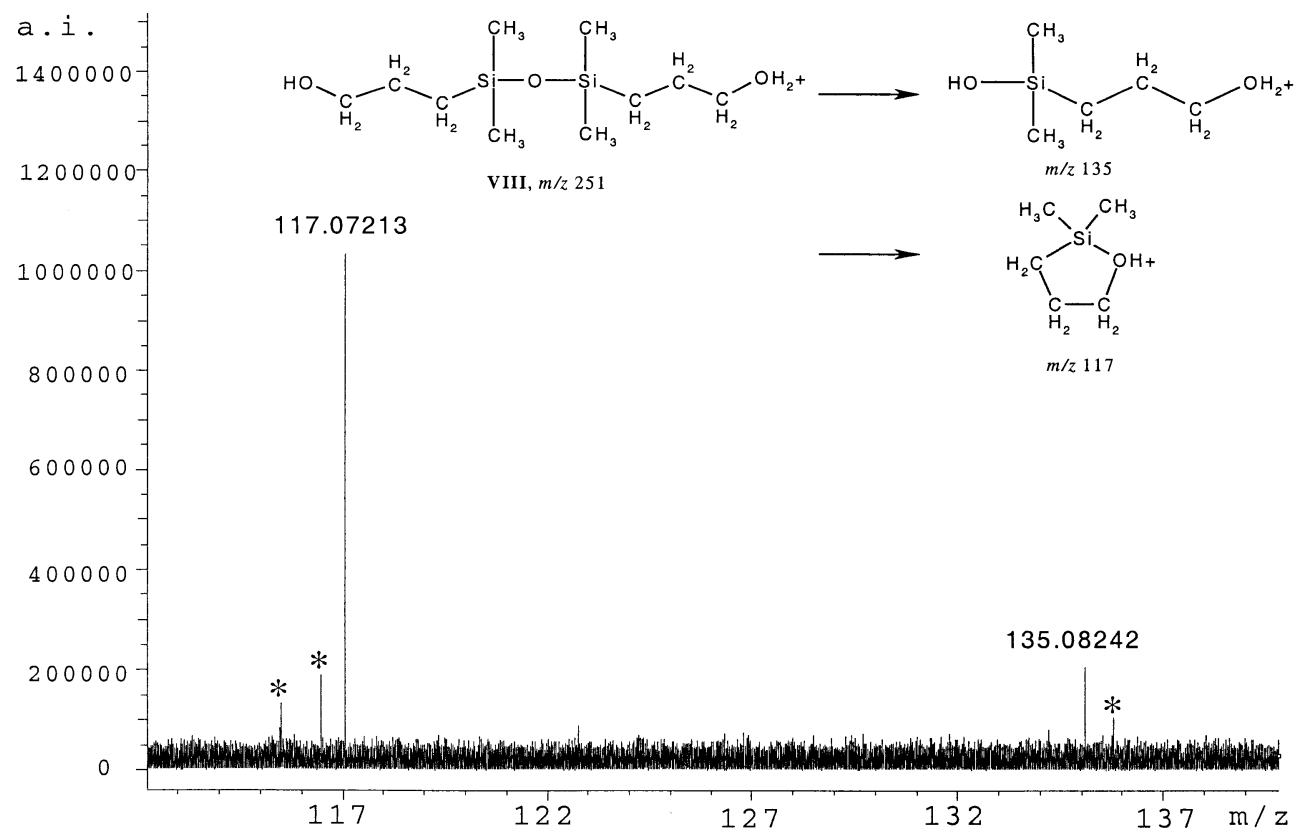

Figure 4. SORI-CID spectrum of the $[\mathrm{M}+\mathrm{H}]^{+}$ion of VIII $(\mathrm{m} / \mathrm{z} 251)$. The minor peaks are due to electronic noise (asterisk). 


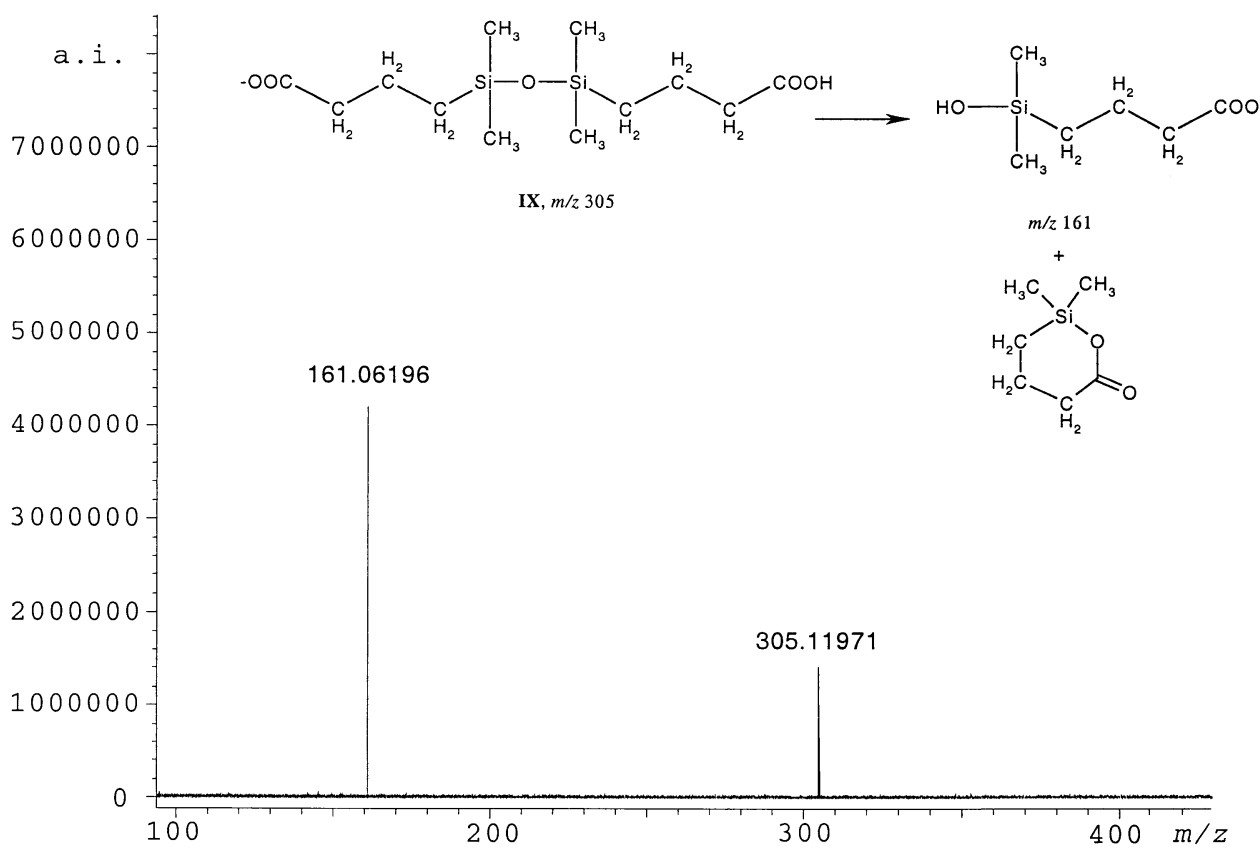

Figure 5. SORI-CID spectrum of the $[\mathrm{M}-\mathrm{H}]^{-}$ion of IX $(\mathrm{m} / \mathrm{z} 305)$.

boxy were found to undergo facile fragmentation reactions in the gas phase to generate silanol-containing species. In this study, 1,3-bis(propylamine)-tetramethyldisiloxane (I) was selected as a model system for the mechanistic study. The unimolecular fragmentation of its protonated ion, II, was explored by tandem mass spectrometry using ESI-FTICR MS coupled with an H/D exchange experiment, as well as theoretical calculations. SORI-CID of Structure II presumably yields a silanolcontaining product ion and a cyclic product ion. Based upon the experimental results and theoretical calculations, we conclude that a backbiting mechanism that involves the labile hydrogen atoms on the end group is operative. From an energetics stand point, a previously reported mechanism involving hydrogen transfer from the methyl group on silicon [21] is highly unfavorable. In the current

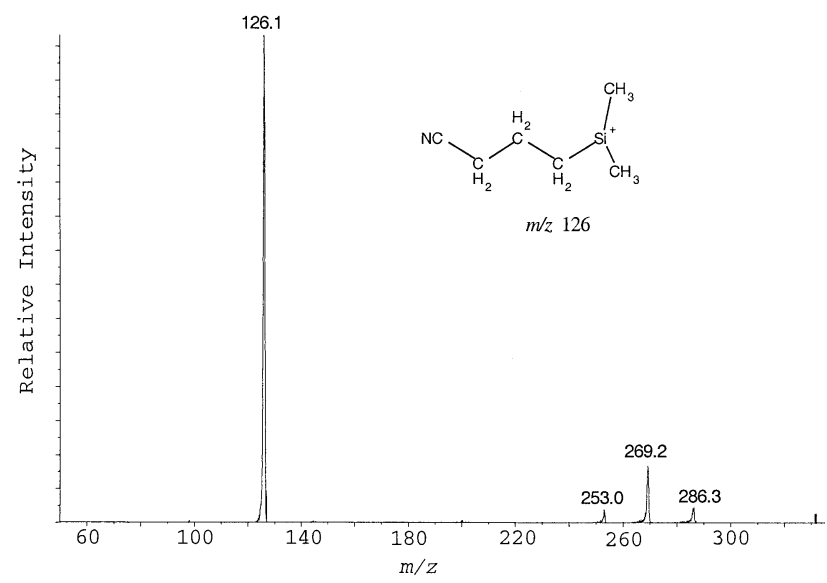

Figure 6. CID spectrum of the $\left[\mathrm{M}+\mathrm{NH}_{4}\right]^{+}$ion of $\mathbf{X}(m / z 286)$. study, two mechanisms were proposed to explain the siloxane bond cleavage and formation of the two product ions. Generation of silanol-containing species requires that the end groups have labile hydrogen atoms. For disiloxane molecules with end groups lacking labile hydrogen atoms (such as $-\mathrm{CN}$ ), direct bond cleavages instead of rearrangements were observed. Overall, fundamental understanding of the gas-phase behavior of these polymer ions helps reduce the complexity of the mass spectral data interpretation. In some cases, certain ions may be artifacts due to the gas-phase fragmentation processes, thus applying softer ionization conditions should help reduce or even eliminate these artifacts. In other cases, certain ions could be due to real impurities in the analyte and designed derivatization experiments should help confirm their structures [21, 22].

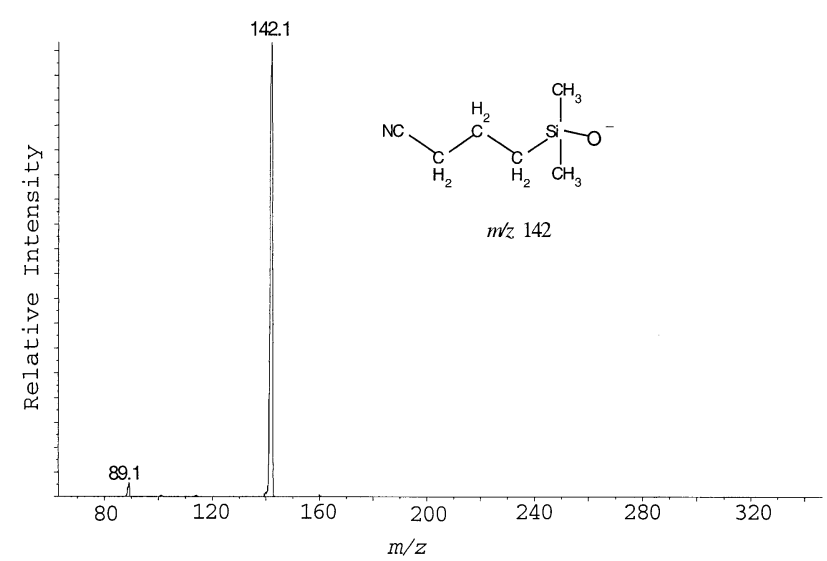

Figure 7. CID spectrum of the $[\mathrm{M}-\mathrm{H}]^{-}$ion of $\mathbf{X I}(\mathrm{m} / \mathrm{z} 286)$. 


\section{Acknowledgments}

The author sincerely appreciates the helpful discussions with Dr. Sheng Wang and Dr. Pengfei Fu. She also gives special thanks to Kurt Brandstadt and Margo McIvor for providing all disiloxane samples.

\section{References}

1. Eaborn, C. Organosilicon Compounds. Butterworths: London, UK, 1960.

2. The Chemistry of Organic Silicon Compounds; Wiley: Chichester, UK; Rappoport Z. Apeloig Y. Eds.; 1998; Vol. II; Patai S.; Rappoport, Z., Eds.; 1989; Vol. I.

3. Brook, M. A. Silicon in Organic, Organometallic, and Polymer Chemistry; John Wiley and Sons, Inc.: New York, NY, 2000.

4. Kelliher, J. T.; Massuda, M.; DiFonzo, P. A.; Neal, T. R. PECVD of Amorphous Silicon Carbide from Trimethylsilane. Mater. Res. Soc. Symp. Proc. 1998, 495, 159.

5. Loboda, M. J. New Solutions for Intermetal Dielectrics Using Trimethylsilane-Based PECVD Processes. Microelectron. Eng. 2000, 50, 15-23.

6. Wendel, S. R.; DiSapio, A. J. Organofunctional Silicones for Personal Care Applications. Cosmetics Toiletries 1983, 98(5), 103.

7. Baney, R. H.; Itoh, M.; Sakakibara, A.; Suzuki, T. Silsesquioxanes. Chem. Rev. 1995, 95, 1409-1430.

8. Provatas, A.; Matisons, J. G. Synthesis and Applications of Silsesquioxanes. Trends Polym. Sci. 1997, 5, 327-333.

9. Moore, J. A. The Analytical Chemistry of Silicones; Smith, A. L., Ed.; John Wiley and Sons, Inc.: New York, NY, 1991; pp 421-470.

10. Karas, M.; Bachmann, D.; Hillenkamp, F. Influence of the Wavelength in High-Irradiance Ultraviolet Laser Desorption Mass Spectrometry of Organic Molecules. Anal. Chem. 1985. 57, 2935-2939.

11. Tanaka, K.; Waki, H.; Ido, Y.; Akita, S.; Yoshida, Y.; Yoshida, T. Protein and Polymer Analyses Up to $m / z$ 100,000 by Laser Ionization Time-of-Flight Mass Spectrometry. Rapid Commun. Mass Spectrom. 1988, 2, 151-153.

12. Hillenkamp, F.; Karas, M.; Beavis, R. C.; Chait, B. T. MatrixAssisted Laser Desorption/Ionization Mass Spectrometry of Biopolymers. Anal. Chem. 1991, 63, 1193A-1203A.

13. Fenn, J. B.; Mann, M.; Meng, C. K.; Wong, S. F.; Whitehouse, C. M. Electrospray Ionization for Mass Spectrometry of Large Biomolecules. Science 1989, 246, 64-71.

14. Kebarle, P.; Tang, L. From Ions in Solution to Ions in the Gas Phase-the Mechanism of Electrospray Mass Spectrometry. Anal. Chem. 1993, 65, 927A-986A.

15. Wallace, W. E.; Guttman, C. M.; Antonucci, J. M. Molecular Structure of Silsesquioxanes Determined by Matrix-Assisted Laser Desorption/Ionization Time-of-Flight Mass Spectrometry. J. Am. Soc. Mass Spectrom. 1999, 10, 224-230.

16. Wallace, W. E.; Guttman, C. M.; Antonucci, J. M. Polymeric Silsesquioxanes: Degree-of-Intramolecular-Condensation Studied by Mass Spectrometry. Polymer 2000, 41, 2219-2226.

17. Tecklenburg, R. E.; Wallace, W. E.; Chen, H. Characterization of a $\left[\left(\mathrm{O}_{3 / 2} \mathrm{SiMe}\right)_{\mathrm{x}}(\mathrm{OSi}\{\mathrm{OH}\} \mathrm{Me})_{\mathrm{y}}\left(\mathrm{OSiMe}_{2}\right)_{\mathrm{z}}\right]$ Silsesquioxane Copolymer Resin by Mass Spectrometry. Rapid Commun. Mass Spectrom. 2001, 15, 2176-2185.

18. Fasce, D. P.; Williams, R. J. J.; Erra-Balsells, R.; Ishikawa, Y.; Nonami, H. One-Step Synthesis of Polyhedral Silsesquioxanes Bearing Bulky Substituents: UV-MALDI-TOF and ESI-TOF Mass Spectrometry Characterization of Reaction Products. Macromolecules 2001, 34, 3534-3539.
19. Bujalski, D. R.; Chen, H.; Tecklenburg, R. E.; Moyer, E. S.; Zank, G. A.; Su, K. Compositional and Structural Analysis of a $\left(\mathrm{PhSiO}_{3 / 2}\right)_{0.35}\left(\mathrm{MeSiO}_{3 / 2}\right)_{0.40}\left(\mathrm{Me}_{2} \mathrm{ViSiO}_{1 / 2}\right)_{0.25}$ Resin. Macromolecules 2003, 36, 180-197.

20. Bujalski, D. R.; Chen, H.; Zank, G. A.; Su, K. Synthesis of $\left(\mathrm{PhSiO}_{3 / 2}\right)_{0.35}\left(\mathrm{MeSiO}_{3 / 2}\right)_{0.40}\left(\mathrm{Me}_{2} \mathrm{ViSiO}_{1 / 2}\right)_{0.25}$ Resins. Macromolecules 2003, in press.

21. Maziarz, E. P., III; Baker, G. A.; Wood, T. D. Capitalizing on the High Mass Accuracy of Electrospray Ionization Fourier Transform Mass Spectrometry for Synthetic Polymer Characterization: A Detailed Investigation of Poly(Dimethylsiloxane). Macromolecules 1999, 32, 4411-4418.

22. Maziarz, E. P., III; Liu, X. M.; Quinn, E. T.; Lai, Y.-C.; Ammon, D. M.; Grobe, G. L., III. Detailed Analysis of $\alpha, \omega$-bis $(4-$ Hydroxybutyl) poly(Dimethylsiloxane) Using GPC-MALDI TOF Mass Spectrometry. J. Am. Soc. Mass Spectrom. 2002, 13, 170-176.

23. Gard, E.; Willard, D.; Bregar, J.; Green, M. K.; Lebrilla, C. B. Site Specificity in the H/D Exchange Reactions of Gas-Phase Protonated Amino Acids and $\mathrm{CH}_{3} \mathrm{OD}$. Org. Mass Spectrom. 1993, 28, 1632-1639.

24. Lee, S.-W.; Lee, H. N.; Kim, H. S.; Beauchamp, J. L. Selective Binding of Crown Ethers to Protonated Peptides Can Be Used to Probe Mechanisms of H/D Exchange and Collision-Induced Dissociation Reactions in the Gas Phase. J. Am. Chem. Soc. 1998, 120, 5800-5805.

25. Freitas, M. A.; Marshall, A. G. Rate and Extent of Gas-Phase Hydrogen/Deuterium Exchange of Bradykinins: Evidence for Peptide Zwitterions in the Gas Phase. Int. J. Mass Spectrom. 1999, 182/183, 221-231.

26. Gauthier, J. W.; Trautman, T. R.; Jacobson, D. B. Sustained Off-Resonance Irradiation for Collision-Activated Dissociation Involving Fourier-Transform Mass-Spectrometery CollisionActivated Dissociation Technique That Emulates Infrared Multiphoton Dissociation. Anal. Chim. Acta 1991, 246, 211-225.

27. Frisch, M. J.; Trucks, G. W.; Schlegel, H. B.; Scuseria, G. E.; Robb, M. A.; Cheeseman, J. R.; Zakrzewski, V. G.; Montgomery, J. A.; Stratmann, R. E.; Burant, J. C.; Dapprich, S.; Millam, J. M.; Daniels, A. D.; Kudin, K. N.; Strain, M. C.; Farkas, O.; Tomasi, J.; Barone, V.; Cossi, M.; Cammi, R.; Mennucci, B.; Pomelli, C.; Adamo, C.; Clifford, S.; Ochterski, J.; Petersson, G. A.; Ayala, P. Y.; Cui, Q.; Morokuma, K.; Malick, D. K.; Rabuck, A. D.; Raghavachari, K.; Foresman, J. B.; Cioslowski, J.; Ortiz, J. V.; Baboul, A. G.; Stefanov, B. B.; Liu, G.; Liashenko, A.; Piskorz, P.; Komaromi, I.; Gomperts, R.; Martin, R. L.; Fox, D. J.; Keith, T.; Al-Laham, M. A.; Peng, C. Y.; Nanayakkara, A.; Challacombe, M.; Gill, P. M. W.; Johnson, B.; Chen, W.; Wong, M. W.; Andres, J. L.; Gonzalez, C.; Head-Gordon, M.; Replogle, E. S.; Pople, J. A. Gaussian 98; Revision A.9. Gaussian, Inc: Pittsburgh, PA, 1998.

28. Foresman, J. B.; Frisch, A. Exploring Chemistry with Electronic Structure Methods; 2nd ed. Gaussian, Inc.: Pittsburgh, PA, 1996; pp 141-161.

29. March, J. Advanced Organic Chemistry, 4th ed.; Wiley: New York, 1992; pp 326-327.

30. Sommer, L. Stereochemistry, Mechanism, and Silicon; McGraw Hill: New York 1965; 84-91, 97-100.

31. Cypryk, M.; Apeloig, Y. Ab Initio Study of Silyloxonium Ions. Organometallics 1997, 16, 5938-5949.

32. Lias, S. G.; Bartmess, J. E.; Liebmen, J. F.; Holmes, J. L.; Levin, R. D.; Mallard, W. G. Gas-Phase Ion and Neutral Thermochemistry. J. Phys. Chem. Ref. Data 1988, 17, Suppl. No. 1 Thermochemical data was taken from the reference. 